\title{
19. PALEOCENE BENTHIC FORAMINIFERAL BIOFACIES AND SEQUENCE STRATIGRAPHY, ISLAND BEACH BOREHOLE, NEW JERSEY ${ }^{1}$
}

\author{
Chengjie Liu, ${ }^{2}$ James V. Browning, ${ }^{2}$ Kenneth G. Miller, ${ }^{2,3}$ and Richard K. Olsson ${ }^{2}$
}

\begin{abstract}
Benthic foraminiferal biofacies and integrated stratigraphic studies of the sediments recovered from the Island Beach borehole in New Jersey reveal that the Paleocene strata penetrated in the borehole can be divided into three sequences, which we designate pa1, pa2, and pa3 in stratigraphically ascending order. Sequence boundaries are recognized by gamma-ray log excursions, hiatuses, and unconformities. Depositional paleoenvironments for each sequence are recognized by lithology and benthic foraminiferal biofacies. Strata in these sequences exhibit upward shallowing from outer neritic to middle neritic environments. Maximum flooding surfaces are associated with the greatest benthic foraminiferal biofacies changes, shell beds, and secondary gamma-ray kicks. Biofacies changes across sequence boundaries are less severe; we attribute this to the effects of a longer term decrease in water depth superimposed on these shorter-term transgressive/regressive cycles.
\end{abstract}

\section{INTRODUCTION}

One of the primary objectives of the New Jersey Coastal Plain Drilling Project of the Ocean Drilling Program (ODP) Leg 150X was to provide data on the timing and magnitudes of sea-level changes (see summary by Miller, Chapter 1, this volume). The Paleocene is of interest to sea-level studies, because it is generally considered to be an interval lacking large ice sheets (Miller et al., 1987). Haq et al. (1987) reported large, rapid (>150 $\mathrm{m}$ in <1 m.y.) Paleocene sea-level changes. This poses an enigma, because only ice-volume changes have been employed to explain large, rapid sea-level changes (Pitman and Golovchenko, 1983). However, the validity of the Haq et al. (1987) record is unclear, because the data on which they are based have not been released.

New Jersey provides an ideal passive margin for study of Paleocene sea-level changes and sequence stratigraphic studies because of relatively quiescent subsidence (Steckler and Watts, 1979), good biostratigraphic control (Olsson and Wise, 1987a, 1987b), and relatively low rates of sediment supply (Poag and Sevon, 1989). Olsson and Wise $(1987 a, 1987 b)$ reported on upper Maastrichtian to middle Eocene sequences and water depth changes in the New Jersey Coastal Plain and compared their results to those of Haq et al. (1987). They concluded that there was a good match between the cycle chart and the record of deposition in New Jersey; however, their estimates for the amplitude of sea-level changes were much smaller than those of Haq et al. (1987). The study of Olsson and Wise (1987b) was limited by lack of continuously sampled boreholes.

Although Eocene and younger sediments were encountered in all sites drilled by ODP Leg 150X, the Paleocene and Upper Cretaceous were reached only at Island Beach. This study focuses on sequence stratigraphy of the Paleocene strata recovered at Island Beach (Fig. 1). We (1) recognize sequences using physical stratigraphy (see Miller et al., 1994 for detailed descriptions); (2) date them using planktonic (foraminiferal and nannofossil) biostratigraphy; (3) infer water depth changes within the sequences using benthic foraminiferal biofacies studies; and (4) interpret systems tracts based on litho-

${ }^{1}$ Miller, K.G., and Snyder, S.W. (Eds.), 1997. Proc. ODP, Sci. Results, 150X: College Station, TX (Ocean Drilling Program).

${ }^{2}$ Department of Geological Sciences, Rutgers University, Piscataway, NJ 08854 U.S.A. cheliu@rci.rutgers.edu

${ }^{3}$ Lamont-Doherty Earth Observatory of Columbia University, Palisades, NY 10964, U.S.A. stratigraphy (Miller et al., 1994; Owens et al., Chapter 2, this volume), well logs, and paleodepth changes (Figs. 1-3).

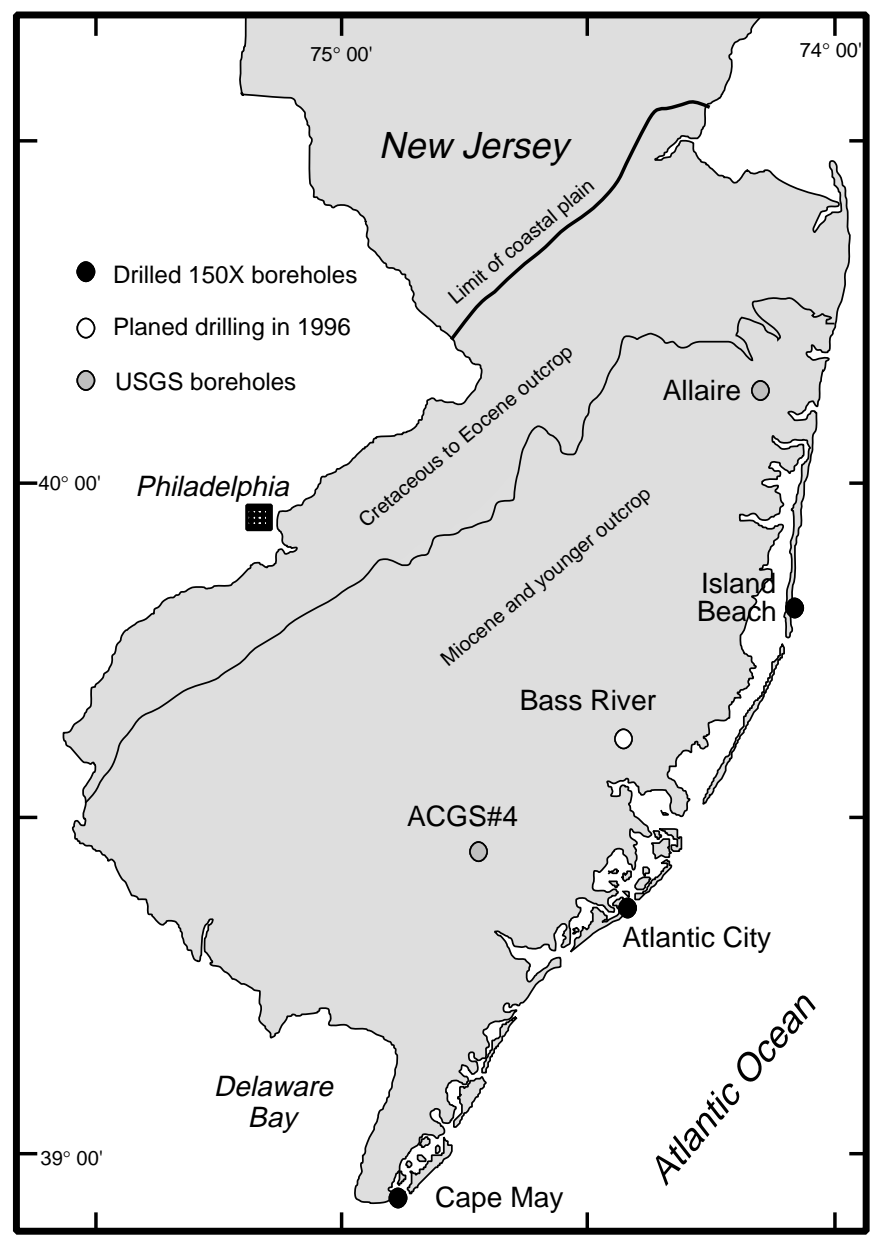

Figure 1. Location map of the New Jersey Coastal Plain Drilling, showing three Leg 150X boreholes, two USGS boreholes that were previously drilled, and one borehole to be drilled in 1996. 


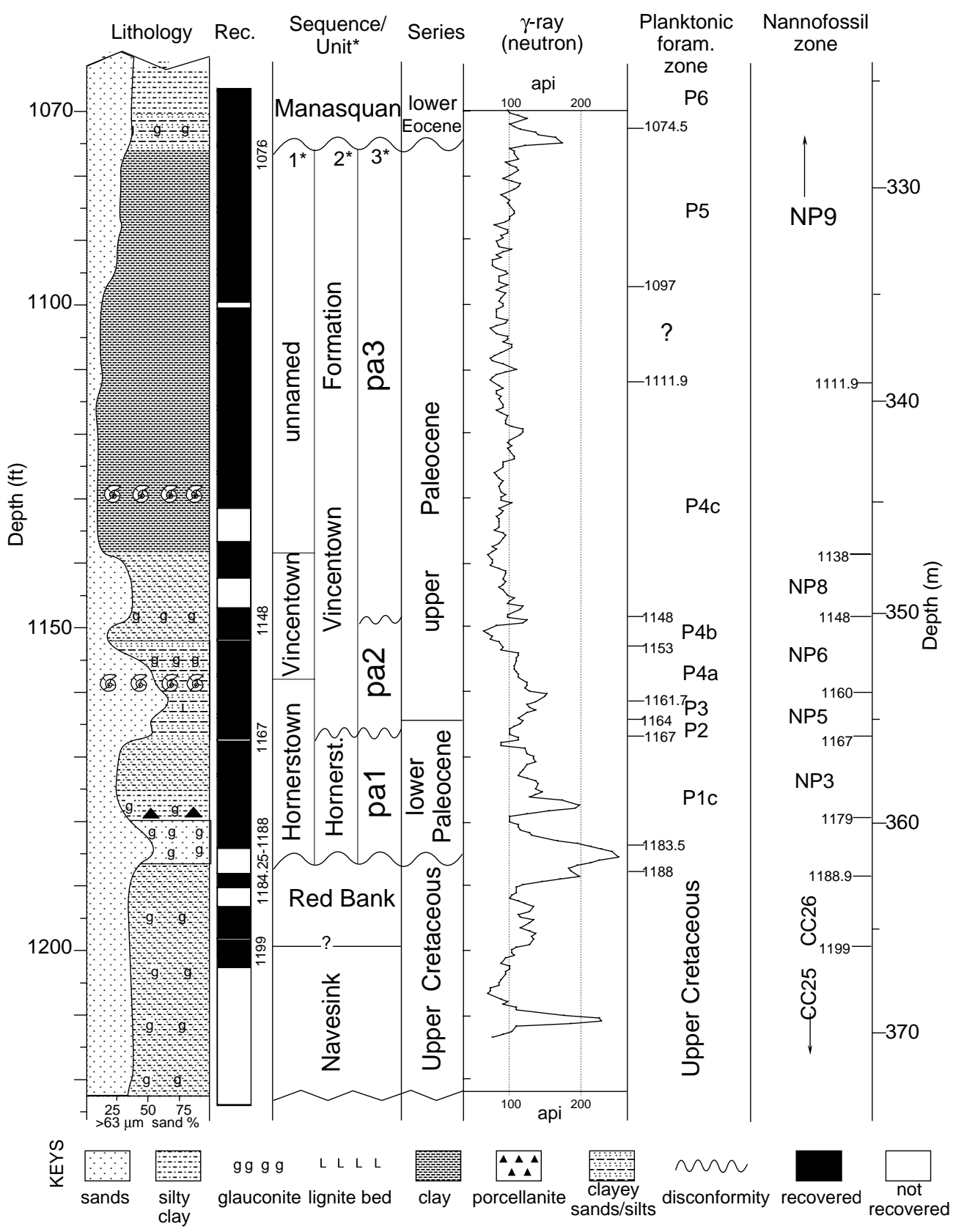

Figure 2. Lithostratigraphy, gamma-ray log, and biostratigraphy of the Paleocene strata at Island Beach, New Jersey. $1 *=$ formational assignment of Owens and Minard (1964), Olsson and Wise (1987a, 1987b), and Olsson (1991); $2^{*}=$ formational assignment of Owens et al. (Chapter 2, this volume); and $3^{*}=$ sequence stratigraphic nomenclature of this study. Shell symbol $=$ shell beds. Solid triangles = porcellanite/porcellanitic clays.

\section{METHODS}

Most of the samples used in this study are $10-20 \mathrm{~cm}^{3}$ in volume (typically $20-30 \mathrm{~g}$ ), and were originally taken for planktonic foraminiferal biostratigraphic study. Processing procedures and methods are described in detail in Liu et al. (Chapter 10, this volume). Larger samples, up to $50 \mathrm{~cm}^{3}$ (typically $60-80 \mathrm{~g}$ ), were obtained in less fossiliferous intervals and processed in the same manner. Benthic foraminiferal specimens from the greater than $100-\mu \mathrm{m}$ size fraction were picked, identified, and counted for biofacies study. We chose $100 \mu \mathrm{m}$ because many specimens are less than $150 \mu \mathrm{m}$, the size that traditionally has been used for studies of this type. The number of foraminiferal specimens per gram of sample was computed from the greater than $63-\mu \mathrm{m}$ size fraction. The percentage of planktonic foraminifers was calculated for samples containing common to abundant specimens $(>100 / \mathrm{g})$.

Of the 30 Paleocene samples analyzed for benthic foraminiferal biofacies, seven samples have very few specimens $(<5 / \mathrm{g})$. Three samples have more than five but fewer than 100 specimens/g. All others contain common $(100-499 / \mathrm{g})$ to abundant $(>500 / \mathrm{g})$ foraminifers. Cluster analysis was performed on the data set to identify natural assemblages of organisms (biofacies). One hundred nineteen taxa were identified; however, 51 taxa with single occurrences were excluded from the cluster analysis. Presence/absence data were analyzed to include the samples with low abundances. Q-mode cluster analysis was performed on 30 samples containing 68 taxa. A Pearson correlation coefficient distance of $<0.65$ was arbitrarily chosen to group samples. The biofacies identified by cluster analysis are interpreted and com- 


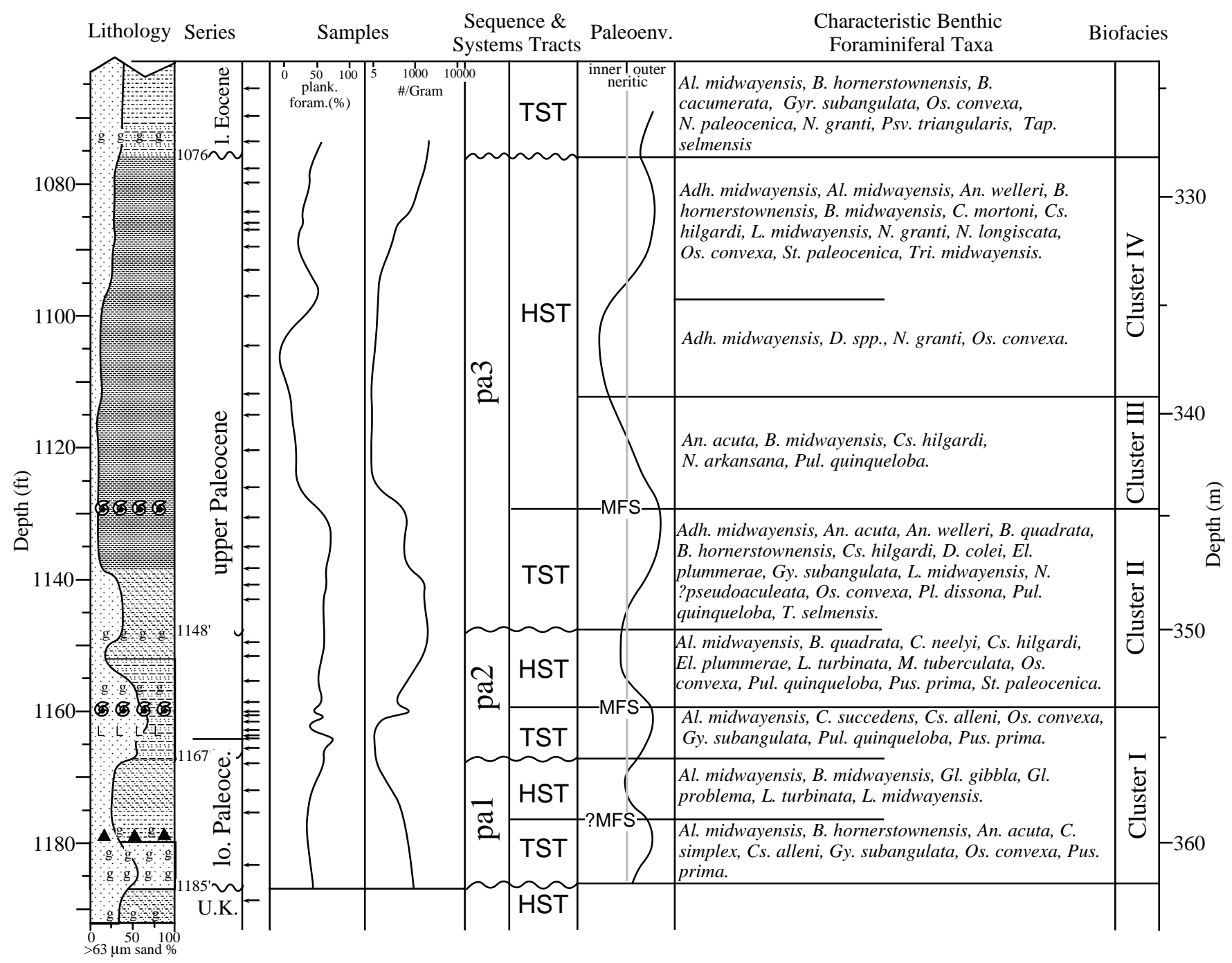

Figure 3. Benthic foraminiferal biofacies, depositional paleoenvironments, and systems tracts. TST $=$ transgressive systems tract; HST $=$ highstand systems tract; and MFS = maximum flooding surface (see key to symbols on Fig. 2).

pared with the sequence stratigraphic results based on lithologic data, biostratigraphic data, qualitative benthic foraminiferal paleobathymetric studies, and gamma-ray logs. Benthic foraminiferal distribution, foraminiferal abundance, and planktonic foraminiferal percentage data are shown in Table 1.

\section{BENTHIC FORAMINIFERAL ECOLOGY}

Many studies indicate that benthic foraminiferal abundance and distribution data are useful for interpreting the paleobathymetry of sediments (e.g. Buzas and Gibson, 1973; Olsson and Wise, 1987b; Olsson, 1991). The distribution of benthic organisms is controlled by both biotic and abiotic parameters. Primary abiotic factors affecting benthic foraminiferal distributions include salinity, temperature, substrate type, dissolved oxygen content, nutrient supply, and current strength (Koutsoukos and Hart, 1990). Important biotic factors include the interrelationships among organisms. The complex interplay of these abiotic and biotic factors controls the distribution of benthic foraminifers. Therefore, benthic foraminiferal taxa show definite specific environmental preferences that can be used to reconstruct past environments. In general, open marine middle-outer neritic to upper bathyal environments have high benthic foraminiferal diversity (Buzas and Gibson,
1973). In addition to benthic foraminiferal distributions, numerous studies show a link between benthic foraminiferal habitats and test morphology (e.g. Lipps, 1976, 1982, 1983; Koutsoukos and Hart, 1990). The relationship between benthic foraminiferal test morphology and paleoenvironment summarized by Koutsoukos and Hart (1990) is adopted in this study.

1. Paralic biotopes. Benthic foraminifers found in marginal marine (estuarine, lagoon) environments are characterized by abundant agglutinated species. Most of these taxa have inferred infaunal habitats with a passive bacterial and detrital scavenging feeding strategy. They generally have elongated morphotypes, varied chamber arrangements and coiling modes, uni- to multiserial and multilocular tests. The minor faunal elements in paralic biotope are epifaunal active herbivores and/or deposit feeders of calcareous-hyaline benthic foraminifers.

2. Neritic biotopes. From inner to outer neritic environments, passive epifaunal and infaunal herbivores decrease in abundance, whereas epifaunal deposit feeders with calcareoushyaline tests, agglutinated tests or calcareous-porcelaneous tests, and infaunal deposit feeders with calcareous-hyaline tests or calcareous-porcelaneous tests increase in abundance. 
Table 1. Island Beach borehole benthic foraminiferal abundance.

\begin{tabular}{|c|c|c|c|c|c|c|c|c|c|c|c|c|c|c|c|c|c|c|c|c|c|c|}
\hline \multirow[b]{2}{*}{ Taxa } & \multicolumn{22}{|c|}{ Sample depth $(\mathrm{ft})$} \\
\hline & 1183.5 & 51175 & 1167.5 & 1164.8 & 1164.3 & 1163 & 1161.7 & 1160.8 & 1158 & 1155 & 1149.5 & 1143.1 & 11141 & 1138 & 1135 & 1130.5 & 1126 & 1120.5 & 51115 & 1111.9 & 1104.91 & 1097 \\
\hline $\begin{array}{l}\text { Adhaerentia midwayensis } \\
\text { Alabamina midwayensis } \\
\text { Allomorphina halli } \\
\text { Angulogerina wilcoxensis } \\
\text { Anomalinoides acuta }\end{array}$ & $\begin{array}{l}9 \\
1 \\
4 \\
\end{array}$ & $\begin{array}{l}3 \\
1\end{array}$ & & & & $\begin{array}{l}3 \\
1\end{array}$ & $\begin{array}{l}4 \\
2\end{array}$ & $\begin{array}{l}8 \\
6\end{array}$ & $\begin{array}{l}2 \\
1\end{array}$ & $\begin{array}{l}3 \\
1\end{array}$ & $\begin{array}{l}7 \\
1 \\
\end{array}$ & 1 & $\begin{array}{l}2 \\
5 \\
3 \\
\end{array}$ & 3 & 3 & 5 & 4 & 3 & 2 & & 8 & \\
\hline $\begin{array}{l}\text { A. danica } \\
\text { A. midwayensis } \\
\text { A. welleri } \\
\text { Bolivina midwayensis } \\
\text { Bulimina cacumerata }\end{array}$ & 2 & 3 & & 1 & & 1 & $\begin{array}{l}7 \\
1\end{array}$ & 3 & 2 & & & $\begin{array}{l}1 \\
1 \\
1\end{array}$ & $\begin{array}{l}1 \\
6 \\
3\end{array}$ & 1 & $\begin{array}{l}2 \\
3\end{array}$ & 6 & & & & & & \\
\hline $\begin{array}{l}\text { Bulimina hornerstownensis } \\
\text { B. midwayensis } \\
\text { B. pseduocacumerata } \\
\text { B. quadrata } \\
\text { Bullopora sp. }\end{array}$ & $\begin{array}{l}8 \\
2\end{array}$ & $\begin{array}{l}4 \\
1 \\
\end{array}$ & & $\begin{array}{l}6 \\
2\end{array}$ & $\begin{array}{l}4 \\
3\end{array}$ & 1 & $\begin{array}{c}10 \\
3\end{array}$ & $\begin{array}{c}15 \\
1\end{array}$ & $\begin{array}{l}2 \\
1 \\
1 \\
\end{array}$ & $\begin{array}{l}9 \\
8\end{array}$ & $\begin{array}{l}5 \\
4\end{array}$ & $\begin{array}{c}13 \\
1 \\
4\end{array}$ & $\begin{array}{l}7 \\
1 \\
3\end{array}$ & $\begin{array}{l}1 \\
4\end{array}$ & $\begin{array}{l}1 \\
6 \\
2\end{array}$ & $\begin{array}{l}2 \\
1\end{array}$ & 1 & 1 & 2 & $\begin{array}{l}1 \\
1\end{array}$ & & \\
\hline $\begin{array}{l}\text { Ceratobulimina perplexa } \\
\text { Cibicides blanpiedi } \\
\text { C. mortoni } \\
\text { C. neelyi } \\
\text { C. simplex }\end{array}$ & 15 & 2 & & & 2 & 2 & 1 & $\begin{array}{l}3 \\
3 \\
2 \\
\end{array}$ & 3 & 6 & & & 2 & & & 1 & & 1 & 1 & & & \\
\hline $\begin{array}{l}\text { C. succedens } \\
\text { Cibicidoides alleni } \\
\text { C. hilgardi } \\
\text { Dentalina colei } \\
\text { D. communis }\end{array}$ & 10 & $\begin{array}{l}1 \\
1 \\
2\end{array}$ & 1 & 2 & $\begin{array}{l}5 \\
7\end{array}$ & $\begin{array}{l}4 \\
2\end{array}$ & $\begin{array}{c}11 \\
7\end{array}$ & $\begin{array}{c}12 \\
1 \\
2 \\
1\end{array}$ & $\begin{array}{l}2 \\
1\end{array}$ & $\begin{array}{l}1 \\
4 \\
2 \\
1\end{array}$ & $\begin{array}{c}1 \\
51 \\
1 \\
1\end{array}$ & $\begin{array}{l}1 \\
1 \\
1\end{array}$ & $\begin{array}{c}5 \\
14 \\
2 \\
1\end{array}$ & $\begin{array}{l}2 \\
7\end{array}$ & 18 & $\begin{array}{c}2 \\
5 \\
10 \\
1\end{array}$ & 2 & 4 & 1 & $\begin{array}{l}1 \\
1\end{array}$ & & \\
\hline $\begin{array}{l}\text { D. pauperata } \\
\text { D. plummerae } \\
\text { Dentalina sp. } \\
\text { Ellipsonodosaria plummerae } \\
\text { Glandulina laevigata } \\
\end{array}$ & 2 & 9 & 1 & $\begin{array}{l}1 \\
1\end{array}$ & 2 & $\begin{array}{l}1 \\
6\end{array}$ & $\begin{array}{l}2 \\
6\end{array}$ & & 2 & $\begin{array}{l}1 \\
1\end{array}$ & 2 & $\begin{array}{c}1 \\
23\end{array}$ & $\begin{array}{c}1 \\
1 \\
13 \\
3\end{array}$ & $\begin{array}{l}1 \\
2 \\
4 \\
2\end{array}$ & 1 & 3 & 2 & & 1 & & 2 & 1 \\
\hline $\begin{array}{l}\text { Globulina gibba } \\
\text { G. problema } \\
\text { Gyroidinoides subangulata } \\
\text { Lagena sulcata } \\
\text { Lenticulina degolyeri }\end{array}$ & $\begin{array}{l}1 \\
9\end{array}$ & $\begin{array}{c}5 \\
11 \\
1 \\
2 \\
\end{array}$ & & 1 & $\begin{array}{l}1 \\
1 \\
\end{array}$ & $\begin{array}{c}12 \\
2\end{array}$ & $\begin{array}{c}2 \\
4 \\
16 \\
3 \\
4\end{array}$ & $\begin{array}{l}3 \\
3 \\
1 \\
7\end{array}$ & $\begin{array}{l}1 \\
1 \\
1\end{array}$ & $\begin{array}{l}6 \\
1 \\
3\end{array}$ & $\begin{array}{l}2 \\
3\end{array}$ & $\begin{array}{l}1 \\
4\end{array}$ & $\begin{array}{l}1 \\
2\end{array}$ & 3 & 5 & $\begin{array}{l}4 \\
2 \\
1 \\
\end{array}$ & & & & & & \\
\hline $\begin{array}{l}\text { L. hornerstownensis } \\
\text { L. midwayensis } \\
\text { L. orbicularis } \\
\text { L. rotulata } \\
\text { L. turbinata }\end{array}$ & $\begin{array}{l}1 \\
1 \\
\end{array}$ & $\begin{array}{l}25 \\
11 \\
\end{array}$ & $\begin{array}{l}2 \\
1 \\
\end{array}$ & 4 & & 2 & $\begin{array}{l}1 \\
5\end{array}$ & $\begin{array}{l}2 \\
1\end{array}$ & $\begin{array}{l}1 \\
3 \\
3\end{array}$ & 1 & $\begin{array}{l}1 \\
2 \\
5 \\
\end{array}$ & 2 & 6 & 1 & 2 & 4 & 1 & & & & & \\
\hline $\begin{array}{l}\text { Marginulinopsis tuberculata } \\
\text { Nodosaria arkansana } \\
\text { N. attenuata } \\
\text { N. granti } \\
\text { N. longiscata }\end{array}$ & & 2 & & & 2 & & 1 & 3 & $\begin{array}{l}1 \\
1 \\
1 \\
1\end{array}$ & 3 & 3 & $\begin{array}{l}1 \\
5 \\
\end{array}$ & & 3 & $\begin{array}{l}2 \\
1 \\
1 \\
4 \\
\end{array}$ & $\begin{array}{l}1 \\
2 \\
2 \\
2 \\
\end{array}$ & 1 & 3 & & & & \\
\hline $\begin{array}{l}\text { N. paleocenica } \\
\text { N. ?psedudoaculeata } \\
\text { N. spinescens } \\
\text { N. spinosa } \\
\text { Nodosaria } \text { sp. }\end{array}$ & & 1 & & & 1 & & 1 & $\begin{array}{l}1 \\
1\end{array}$ & 2 & $\begin{array}{l}2 \\
1 \\
\end{array}$ & & 15 & 11 & 15 & $\begin{array}{l}4 \\
2 \\
\end{array}$ & 18 & & & & & & \\
\hline $\begin{array}{l}\text { Osangularia convexa } \\
\text { Pararotalia perclara } \\
\text { Planularia dissona } \\
\text { P. toddae } \\
\text { Pseudouvigerina triangularis }\end{array}$ & $\begin{array}{l}6 \\
1 \\
\end{array}$ & 3 & & & & 25 & $\begin{array}{l}12 \\
2\end{array}$ & $\begin{array}{l}23 \\
2 \\
3 \\
\end{array}$ & 3 & 1 & 8 & $\begin{array}{l}1 \\
2 \\
2\end{array}$ & $\begin{array}{l}7 \\
2 \\
6\end{array}$ & $\begin{array}{l}2 \\
1 \\
2\end{array}$ & $\begin{array}{c}15 \\
1\end{array}$ & $\begin{array}{l}5 \\
2\end{array}$ & & & 1 & 1 & 1 & 1 \\
\hline $\begin{array}{l}\text { P. naheolensis } \\
\text { P. seligi } \\
\text { Pullenia quinqueloba } \\
\text { Pulsiphonina prima } \\
\text { Ramulina globulifera } \\
\end{array}$ & 8 & & & & 2 & 2 & $\begin{array}{l}2 \\
13\end{array}$ & $\begin{array}{c}10 \\
6 \\
1 \\
\end{array}$ & 1 & 7 & $\begin{array}{c}9 \\
11\end{array}$ & 2 & & $\begin{array}{l}2 \\
1 \\
1 \\
\end{array}$ & $\begin{array}{l}3 \\
2\end{array}$ & $\begin{array}{l}6 \\
1\end{array}$ & 1 & & & & 1 & 1 \\
\hline $\begin{array}{l}\text { Rectonodosaria manifesta } \\
\text { Siphogenerina eleganta } \\
\text { Stilostomella paleocenica } \\
\text { Tappanina selmensis } \\
\text { Tritaxia midwayensis }\end{array}$ & $\begin{array}{l}1 \\
1 \\
\end{array}$ & & & & 2 & 1 & 1 & $\begin{array}{l}3 \\
1 \\
6\end{array}$ & 2 & 4 & 26 & $\begin{array}{l}2 \\
4\end{array}$ & 73 & $\begin{array}{l}1 \\
2\end{array}$ & $\begin{array}{l}4 \\
1 \\
4 \\
\end{array}$ & $\begin{array}{l}2 \\
1 \\
3 \\
\end{array}$ & 1 & 1 & & & & \\
\hline $\begin{array}{l}\text { Vaginulinopsis echinata } \\
\text { V. midwayana }\end{array}$ & & $\begin{array}{l}5 \\
1 \\
\end{array}$ & 1 & & & & & & 2 & 1 & & & 2 & 1 & & & & & & & & \\
\hline Specimens $(>63 \mu \mathrm{m}) / \mathrm{g}$ : & 986 & 647 & $<5$ & $<5$ & $<5$ & 42 & 587 & 914 & 579 & 827 & 2247 & 1461 & 2134 & 692 & 798 & 874 & $<5$ & $<5$ & $<5$ & $<5$ & 35 & 72 \\
\hline Planktonic foraminifer $(\%)$ : & 44.2 & 34 & 58.3 & 77.1 & 63.3 & 37.9 & 61.9 & 31.1 & 54.4 & 41.8 & 55.9 & 55.0 & 59.8 & 57.1 & 68.1 & 66.7 & 12.3 & 19.6 & 26.0 & 28.6 & 2.4 & \\
\hline
\end{tabular}

The outer limit for passive epifaunal herbivores with calcareous-hyaline or agglutinated tests is the outer neritic zone. Suspension feeders with agglutinated tests begin to occur in outer shelf environments.

3. Slope biotopes. Infaunal deposit feeders with calcareoushyaline or calcareous-porcelaneous tests reach highest abun- dances in the upper bathyal zone, and they decrease sharply toward the lower bathyal zone. Epifaunal deposit feeders with calcareous-hyaline, agglutinated, or calcareous-porcelaneous tests do not show significant change in bathyal environments. Suspension feeders with agglutinated tests increase in abundance from upper to lower bathyal environments. 
Table 1. (continued)

\begin{tabular}{|c|c|c|c|c|c|c|c|c|}
\hline \multirow[b]{2}{*}{ Taxa } & \multicolumn{8}{|c|}{ Sample depth (ft) } \\
\hline & 1093.5 & 51089 & 1087 & 1086 & 1084 & 1080 & 1077.5 & 1074.5 \\
\hline $\begin{array}{l}\text { Adhaerentia midwayensis } \\
\text { Alabamina midwayensis } \\
\text { Allomorphina halli } \\
\text { Angulogerina wilcoxensis } \\
\text { Anomalinoides acuta }\end{array}$ & $\begin{array}{l}3 \\
2\end{array}$ & 17 & $\begin{array}{l}1 \\
4\end{array}$ & $\begin{array}{l}1 \\
3\end{array}$ & $\begin{array}{l}2 \\
5\end{array}$ & 2 & $\begin{array}{l}3 \\
1 \\
\end{array}$ & $\begin{array}{l}7 \\
2 \\
7\end{array}$ \\
\hline $\begin{array}{l}\text { A. danica } \\
\text { A. midwayensis } \\
\text { A. welleri } \\
\text { Bolivina midwayensis } \\
\text { Bulimina cacumerata }\end{array}$ & 1 & 1 & 2 & 1 & 1 & 1 & 4 & 15 \\
\hline $\begin{array}{l}\text { Bulimina hornerstownensis } \\
\text { B. midwayensis } \\
\text { B. pseduocacumerata } \\
\text { B. quadrata } \\
\text { Bullopora } \mathrm{sp} .\end{array}$ & $\begin{array}{l}1 \\
1\end{array}$ & 7 & $\begin{array}{l}3 \\
2\end{array}$ & $\begin{array}{l}5 \\
9\end{array}$ & & 3 & $\begin{array}{l}1 \\
1\end{array}$ & $\begin{array}{l}8 \\
5 \\
4\end{array}$ \\
\hline $\begin{array}{l}\text { Ceratobulimina perplexa } \\
\text { Cibicides blanpiedi } \\
\text { C. mortoni } \\
\text { C. neelyi } \\
\text { C. simplex } \\
\end{array}$ & & 3 & $\begin{array}{l}2 \\
1\end{array}$ & 1 & & $\begin{array}{l}2 \\
2\end{array}$ & & $\begin{array}{l}1 \\
2\end{array}$ \\
\hline $\begin{array}{l}\text { C. succedens } \\
\text { Cibicidoides alleni } \\
\text { C. hilgardi } \\
\text { Dentalina colei } \\
\text { D. communis }\end{array}$ & & & 6 & $\begin{array}{l}4 \\
2\end{array}$ & $\begin{array}{c}1 \\
12\end{array}$ & $\begin{array}{c}3 \\
23\end{array}$ & $\begin{array}{c}9 \\
1 \\
74 \\
1\end{array}$ & 5 \\
\hline $\begin{array}{l}\text { D. pauperata } \\
\text { D. plummerae } \\
\text { Dentalina sp. } \\
\text { Ellipsonodosaria plummerae } \\
\text { Glandulina laevigata }\end{array}$ & 1 & 1 & $\begin{array}{l}1 \\
2\end{array}$ & 1 & 2 & 1 & 4 & 1 \\
\hline $\begin{array}{l}\text { Globulina gibba } \\
\text { G. problema } \\
\text { Gyroidinoides subangulata } \\
\text { Lagena sulcata } \\
\text { Lenticulina degolyeri }\end{array}$ & & & & & & & 1 & $\begin{array}{l}1 \\
6 \\
1 \\
\end{array}$ \\
\hline $\begin{array}{l}\text { L. hornerstownensis } \\
\text { L. midwayensis } \\
\text { L. orbicularis } \\
\text { L. rotulata } \\
\text { L. turbinata } \\
\end{array}$ & 1 & & 1 & 2 & & $\begin{array}{l}2 \\
1\end{array}$ & 2 & 3 \\
\hline $\begin{array}{l}\text { Marginulinopsis tuberculata } \\
\text { Nodosaria arkansana } \\
\text { N. attenuata } \\
\text { N. granti } \\
\text { N. longiscata } \\
\end{array}$ & 3 & 2 & 3 & $\begin{array}{l}6 \\
4 \\
\end{array}$ & $\begin{array}{l}1 \\
2 \\
\end{array}$ & 1 & $\begin{array}{l}4 \\
2 \\
\end{array}$ & 5 \\
\hline $\begin{array}{l}\text { N. paleocenica } \\
\text { N. ?psedudoaculeata } \\
\text { N. spinescens } \\
\text { N. spinosa } \\
\text { Nodosaria } \mathrm{sp} .\end{array}$ & & & 1 & 3 & $\begin{array}{l}1 \\
1 \\
1\end{array}$ & 1 & $\begin{array}{l}1 \\
4 \\
1\end{array}$ & $\begin{array}{l}5 \\
1 \\
\\
5\end{array}$ \\
\hline $\begin{array}{l}\text { Osangularia convexa } \\
\text { Pararotalia perclara } \\
\text { Planularia dissona } \\
\text { P. toddae } \\
\text { Pseudouvigerina triangularis }\end{array}$ & 3 & 3 & 6 & 2 & 10 & & 7 & $\begin{array}{l}5 \\
\\
1 \\
8\end{array}$ \\
\hline $\begin{array}{l}\text { P. naheolensis } \\
\text { P. seligi } \\
\text { Pullenia quinqueloba } \\
\text { Pulsiphonina prima } \\
\text { Ramulina globulifera }\end{array}$ & $\begin{array}{l}1 \\
1\end{array}$ & & $\begin{array}{l}2 \\
1\end{array}$ & & $\begin{array}{l}3 \\
1 \\
1\end{array}$ & 1 & 6 & $\begin{array}{l}2 \\
1\end{array}$ \\
\hline $\begin{array}{l}\text { Rectonodosaria manifesta } \\
\text { Siphogenerina eleganta } \\
\text { Stilostomella paleocenica } \\
\text { Tappanina selmensis } \\
\text { Tritaxia midwayensis }\end{array}$ & $\begin{array}{l}4 \\
1\end{array}$ & $\begin{array}{l}2 \\
3\end{array}$ & $\begin{array}{c}18 \\
1\end{array}$ & $\begin{array}{c}12 \\
1 \\
1\end{array}$ & $\begin{array}{c}5 \\
11\end{array}$ & $\begin{array}{l}3 \\
9\end{array}$ & $\begin{array}{c}2 \\
14\end{array}$ & $\begin{array}{l}2 \\
1\end{array}$ \\
\hline $\begin{array}{l}\text { Vaginulinopsis echinata } \\
\text { V. midwayana }\end{array}$ & & & & & & & 2 & 1 \\
\hline Specimens $(>63 \mu \mathrm{m}) / \mathrm{g}$ : & 114 & 241 & 395 & 672 & 984 & 1108 & 1837 & 2137 \\
\hline Planktonic foraminifer $(\%)$ : & 34.2 & 15.9 & 16.4 & 32.1 & 21.0 & 35.0 & 32.1 & 51.3 \\
\hline
\end{tabular}

\section{SEQUENCE STRATIGRAPHY}

At Island Beach, the Paleocene strata are $109 \mathrm{ft}$ thick (33.2 m) and are separated from the Upper Cretaceous by a very dark clayey glauconite sand layer between 1188.1 and $1183.5 \mathrm{ft}$ (362.2 and $360.8 \mathrm{~m})$.
As in other sections in the New Jersey Coastal Plain (Olsson and Wise, 1987a, 1987b), three Paleocene sequences (pa1, pa2, and pa3) are recognized. Paleocene strata in the New Jersey Coastal Plain have been intensively studied, and three sequences have been previously recognized (e.g., Olsson and Wise, 1987a, 1987b). We name the three Paleocene depositional sequences, in stratigraphically ascending order, pa1, pa2, and pa3 (Figs. 1-3). The lower Paleocene pa1 sequence is bounded by two disconformities and corresponds to the lower Hornerstown Formation. The middle Paleocene pa2 sequence includes the upper Hornerstown Formation (glauconite sands) and Vincentown Formation (silty clay) of Olsson and Wise (1987a, 1987b) and Owens and Minard (1964). Owens et al. (Chapter 2, this volume) assign the basal green sands of pa2 to the Vincentown Formation because they are part of the Vincentown megasequence (pa2 and pa3). We follow Olsson and Wise (1987a, 1987b) in placing these green sands in the subjacent and lithologically similar Hornerstown Formation. Although this results in the formational boundary being above the sequence boundary (Fig. 3), it follows proper procedures in recognizing lithostratigraphic units. The upper Paleocene pa3 sequence (1148-1076 ft [350-328 m] at Island Beach) is massive dark clay that was not well known previously, although Olsson and Wise (1987a) identified a thin interval of unnamed uppermost Paleocene clay, silt, and sands. Owens et al. (Chapter 2, this volume) also assign this clay to the Vincentown Formation. (Figs. 1-3). These differences in formational assignments reflect problems in facies changes between updip outcrops and the downdip Island Beach borehole.

\section{The Pa1 Sequence}

According to Olsson and Wise (1987a, 1987b), the Hornerstown Formation displays lithologic variations among updip/downdip sections. In New Jersey Coastal Plain outcrop and updip subsurface sections, this formation consists of nearly pure glauconite sand. It becomes more clayey (bioturbated and laminated glauconitic silty clay and clayey silt) in subsurface sections downdip. In addition, diachrony among updip/downdip sections is indicated by biostratigraphy. In the updip coastal plain, planktonic foraminiferal Subzone P1c has not been identified, although at the downdip of Island Beach and at the upper slope of Deep Sea Drilling Project (DSDP) Site 605, a thick Subzone P1c was recovered (Fig. 2; Olsson and Wise, 1987a, 1987b).

At Island Beach, the pa1 sequence (lower Hornerstown Formation) occurs between $\sim 1185$ and $1167 \mathrm{ft}(\sim 361.3-355.8 \mathrm{~m})$. This sequence at Island Beach is dated as planktonic foraminiferal Subzone P1c and nannofossil Zone NP3, although older sediments have been found elsewhere in the coastal plain (Liu et al., Chapter 10, this volume). The lower part of the sequence ( 1185-1175 ft [361.3-358.2 $\mathrm{m}]$ ) consists of dark gray, massive, clayey, fine to medium, quartzose glauconite sand containing abundant microfossils. Glauconite content decreases upsection as silt and micaceous clay increase, indicating a fining upward sequence. Planktonic foraminiferal percentages are high $(34 \%-44 \%)$ throughout the pal sequence as are foraminiferal abundances (647-86 specimens/g). Benthic foraminifers at 1183.5 $\mathrm{ft}$ include Cibicidoides alleni and other middle neritic dwellers (Olsson and Wise, 1987b). Compared to the sample at $1183.5 \mathrm{ft}$ (360.8 $\mathrm{m})$, the sample at $1175 \mathrm{ft}(358.2 \mathrm{~m})$ shows a decline of $C$. alleni and a significant increase in middle-outer neritic species of Lenticulina, and other epifaunal deposit feeders (EDF) or infaunal deposit feeders (IDF; e.g., buliminids; Fig. 3). This represents a transgression, and the interval from 1185 to $1175 \mathrm{ft}(361.3-358.2 \mathrm{~m})$ is interpreted as a Transgressive Systems Tract (TST). The maximum flooding surface (MFS) is recognized at $1175 \mathrm{ft}(358.2 \mathrm{~m})$, immediately above a porcellanite bed (Fig. 3).

The upper part of the pa1 sequence (1175-1167 ft [358.2-355.6 $\mathrm{m}]$ ) is dark gray silty clay with visible calcareous microfossils but no macrofossils. This interval exhibits a dramatic decrease in glauconite content and an increase in micaceous and clastic contents. In addition, foraminiferal abundances are very low $(<5$ specimens $/ g)$. The 
benthic foraminiferal diversity declines from 19 to 21 species between 1183.5 and $1175 \mathrm{ft}$ (360.8 and $358.2 \mathrm{~m}$ ) to only six taxa at $1167.5 \mathrm{ft}$ (355.6 m). Benthic foraminifers include middle neritic EDF and IDF such as Lenticulina, Globulina, Bulimina, and Alabamina. Both benthic foraminiferal and lithologic data indicate a middle neritic paleoenvironment. Thus, the section from 1175 to $1167.5 \mathrm{ft}$ (358.2-355.6 m) shallows upward and is interpreted as the highstand systems tract (HST).

\section{The Pa2 Sequence}

The pa2 sequence is well studied in outcrop sections (Olsson and Wise, 1987a, 1987b) where the lower part consists of glauconite greensands (Hornerstown Formation, sensu Olsson and Wise, 1987a, and Owens and Minard, 1964; Vincentown Formation of Owens et al., Chapter 2, this volume), and the upper part consists of inner neritic calcareous sands, fining upward into glauconitic quartzose silts and glauconitic silty clays (Vincentown Formation of Olsson and Wise, 1987a, 1987b). On the continental slope at DSDP Site 605, the upper Paleocene Vincentown Formation equivalent becomes dark greenish gray, clayey chalk with abundant calcareous microfossils. The lithology of the pa2 sequence in the Island Beach borehole section is similar to outcrop sections. The sequence is bounded by unconformities at 1167 and $1148 \mathrm{ft}$ (355.8 and $350 \mathrm{~m}$ ). Estimating the duration of the basal hiatus associated with the pa1/pa2 boundary is difficult. Planktonic foraminiferal biostratigraphy indicates a short (upper Zone P1c to lower P2) hiatus, whereas nannofossil biostratigraphy suggests a much longer (Zone NP4, equivalent to Zone P1cP3b) hiatus of more than 2.5 m.y.

The pa2 sequence is divisible into two systems tracts (TST and HST) by a brachiopod (Olenothyrus harlenii) shell bed at $1158 \mathrm{ft}$ $(353 \mathrm{~m})$. The $1167-1158 \mathrm{ft}(355.8-353.0 \mathrm{~m})$ interval is fine-grained, gray sandy clay or clayey glauconite sands with one lignite layer. Within the interval, diversity of benthic foraminifers increases from 8 to 31 taxa, and foraminiferal abundances increase from $<5$ to 914 specimens/g. This increase in diversity and abundance indicates upward deepening during deposition of the strata, and therefore, this interval is interpreted as a TST. Middle to outer neritic species such as Gyroidinoides subangulata, Osangularia convexa, and Pulsiphonina prima become common near $1158 \mathrm{ft}(353.0 \mathrm{~m})$. The brachiopod shell bed and the elevated foraminiferal abundances indicate a MFS at $1158 \mathrm{ft}(353.0 \mathrm{~m})$

The upper part (1158-1148 $\mathrm{ft}$ [353-350 m]) of the sequence is fine grained, greenish dark gray, bioturbated massive, glauconitic quartzose silty clay with visible microfossils and macrofossils. The most frequently occurring taxa are Cibicidoides hilgardi, Pulsiphonina prima, Ellipsonodosaria plummerae, and Stilostomella paleocenica, indicating shallowing to a middle neritic environment. We interpret this upper part as a HST of the sequence. Although the benthic foraminifers clearly indicate shallowing, planktonic foraminiferal abundances remain high $(41.8 \%-55.9 \%)$ as do overall foraminiferal abundances ( 579 to above 2000 specimens/g).

Sequence pa 2 is separated from pa3 by a short hiatus restricted to planktonic foraminiferal Subzone P4b. The duration of Subzone P4b is $0.6 \mathrm{~m} . \mathrm{y}$.

\section{The Pa3 Sequence}

The pa3 sequence (1148-1076 ft [350-328 m]) is the thickest of the three Paleocene sequences recognized at Island Beach. Although this sequence has not been well documented from previous studies, its equivalent (unnamed clay, silt, sand) has been identified in coastal plain subsurface sections but never in outcrops (Olsson and Wise, 1987a). The sequence itself can be subdivided into three parts, each containing distinct benthic foraminiferal assemblages. Its lower part $(1148-1127.5 \mathrm{ft}$ [343.8-344.5 m]) is massive, fine grained, greenish dark gray, bioturbated, glauconitic sandy clay with visible microfossils and macrofossils. The sand component $(>63 \mu \mathrm{m})$ decreases dramatically from $38 \%$ to less than $10 \%$ within the interval. This interval contains the following benthic foraminifers: Bulimina hornerstownensis, B. quadrata, Cibicidoides hilgardi, Gyroidinoides subangulata, Lenticulina midwayensis, Nodosaria ?pseudoaculeata, Osangularia convexa, Planularia dissona, Pseudouvigerina naheolensis, Pullenia quinqueloba, and Tappanina selmensis. Tappanina selmensis is a typical outer neritic species (Olsson and Wise, 1987a, 1987b). Based on the common occurrence of Tappanina selmensis, the high planktonic foraminiferal percentage $(55 \%-68 \%)$, and the low concentration and decreasing sand content, the $1143-1130.5 \mathrm{ft}$ (348.5$344.7 \mathrm{~m}$ ) interval is interpreted to have been deposited in an outer neritic paleoenvironment and to represent an upward deepening TST of the sequence. A shell bed on top of the interval (1127.5 ft [343.8 $\mathrm{m}]$ ) is interpreted as the MFS.

The middle part of the sequence between 1127.5 and $1111.9 \mathrm{ft}$ ( 343.8 and $339.0 \mathrm{~m}$ ) is massive, dark gray, micaceous clay, with very few microfossils. Three samples (at 1126, 1120.5, and $1115 \mathrm{ft}$ ) were analyzed, and all contain very few foraminifers $(<5$ specimens $/ g)$. Considering the occurrence of the massive micaceous clay and low sand content, this interval is interpreted to represent a prodelta paleoenvironment. This is supported by the extremely high sedimentation rate (Fig. 4).

The upper part (1111.9-1076 ft [343.8-328.1 m]) of the pa3 sequence is massive, dark gray silty clay. It is terminated by a disconformity at $1076 \mathrm{ft}(328.1 \mathrm{~m})$, where the uppermost Paleocene (?) to lower Eocene Manasquan Formation disconformably overlies the Vincentown Formation. Foraminiferal abundances (35-1837 specimens/g), diversity (16-22 species), and sand/silt components all increase upward (Figs. 1,2). The interval is characterized by abundant infaunal and epifaunal deposit feeders and the common occurrence of infaunal suspension feeders (Adhaerentia midwayensis and Tritaxia midwayensis) in the upper part (1089-1076 ft [332-328 m]), indicating an outer neritic depositional environment. We interpret these lithofacies and biofacies changes as reflecting a shift from prodeltaic to middle-outer neritic normal marine paleoenvironments. Thus, although the sequence clearly shallows upsection from the MFS to the lower HST, it deepens again in the upper HST. This anomalous paleoenvironmental change may result from delta lobe switching.

The pa3 sequence is separated from the uppermost Paleocene to lower Eocene Manasquan sequence by a short hiatus restricted to the upper part of planktonic foraminifer Zone P5.

\section{CLUSTER ANALYSIS}

Q-mode cluster analysis divides the samples into four stratigraphically distinct clusters (Clusters I-IV) (Fig. 5). Cluster I includes samples between 1183.5 and $1160.8 \mathrm{ft}$ (360.8-353.9 m), with two samples (at 1175.0 and $1167.5 \mathrm{ft}$ ) excluded. This interval includes the pa1 sequence and the TST of the pa2 sequence. Cluster I is dominated by epifaunal and infaunal deposit feeders, including Alabamina midwayensis, Anomalinoides spp., Bulimina hornerstownensis, B. midwayensis, Cibicides simplex, Cibicidoides alleni, Globulina gibba, G. problema, Gyroidinoides subangulata, Lenticulina midwayensis, L. turbinata, Osangularia convexa, and Pulsiphonina prima. The diversity and abundance of benthic foraminifers in the interval is highest at the bottom, declines in the middle, and then increases toward the top (Table 1).

Cluster II includes the samples between 1158 and $1130.5 \mathrm{ft}$ (353.0-344.7 m), with one sample at $1149.5 \mathrm{ft}$ as an exception (Fig. $5)$. This interval includes the HST of the pa2 sequence and the TST of the pa3 sequence. It is separated from Clusters I and III by two MFSs at 1158.5 and $1127.5 \mathrm{ft}$ (353.2 and $343.8 \mathrm{~m}$; Fig. 3). Benthic foraminifers commonly occurring in this interval include Adhaeren- 

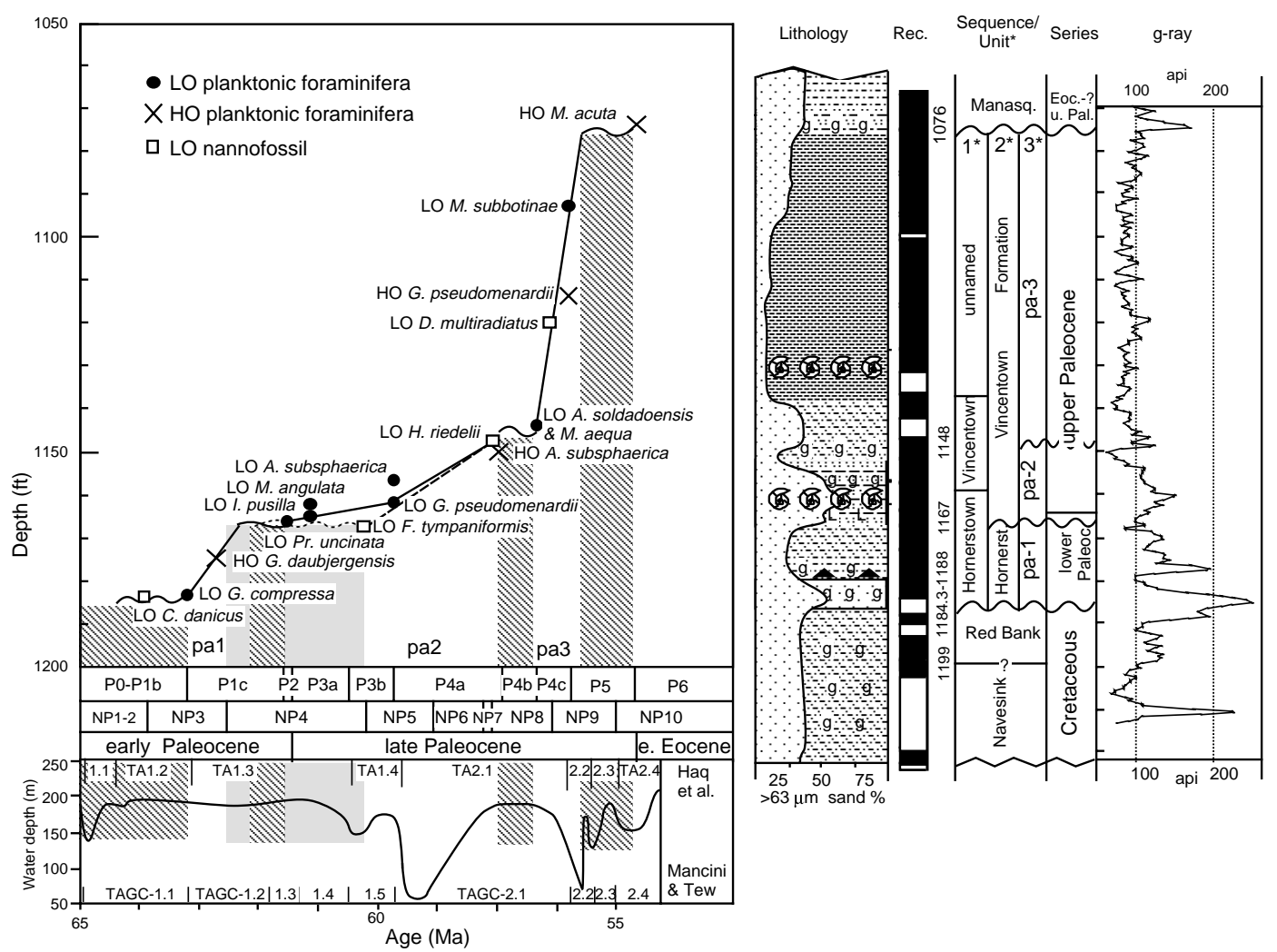

Figure 4. Comparison between sea-level curves of Haq et al. (1987), Mancini and Tew (1991, 1993, 1995), and the Island Beach Paleocene. The age-depth plot of the Island Beach section is based on the planktonic foraminiferal and nannofossil datum events. $\mathrm{LO}=$ lowest occurrence; $\mathrm{HO}=$ highest occurrence. $1^{*}=$ Owens and Minard (1964) and Olsson and Wise (1987a, 1987b); $2^{*}=$ Owens et al. (Chapter 2, this volume); and $3^{*}=$ this study. See key to symbols on Figure 2.

tia midwayensis, Alabamina midwayensis, Anomalinoides acuta, Anomalinoides welleri, Bulimina hornerstownensis, B. quadrata, Cibicides neelyi, Cibicidoides hilgardi, Dentalina colei, Ellipsonodosaria plummerae, Gyroidinoides subangulata, Lenticulina midwayensis, L. turbinata, Marginulinopsis tuberculata, Nodosaria ?pseudoaculeata, Osangularia convexa, Pullenia quinqueloba, Pulsiphonina prima, Stilostomella paleocenica, Tappanina selmensis, and Tritaxia midwayensis. This cluster is also dominated by epifaunal and infaunal deposit feeders. However, the occurrence of infaunal suspension feeders (Adhaerentia midwayensis and Tritaxia midwayensis) in the upper part indicates a deeper water (outer neritic) paleoenvironment.

Cluster III includes only three samples characterized by low abundance and low diversity. Species occurring in these samples are Anomalinoides acuta, Bulimina midwayensis, Cibicidoides hilgardi, Nodosaria arkansana, and Pullenia quinqueloba. This cluster is closely related to Cluster IV. It is found in the lower HST of the pa3 sequence (Fig. 5)

Cluster IV includes the remainder of the samples from the pa3 sequence between 1111.9 and $1076 \mathrm{ft}$ (339.0-328.0 m), consisting of the upper part of the HST (Fig. 3; Table 1). Benthic foraminifers commonly occurring in this interval are Adhaerentia midwayensis, Alabamina midwayensis, Anomalinoides welleri, Bulimina cacumenata, B. hornerstownensis, B. midwayensis, Cibicides mortoni, Cibicidoides hilgardi, Gyroidinoides subangulata, Lenticulina midwayensis, Nodosaria granti, N. longiscata, N. paleocenica, Osangularia convexa, Pseudouvigerina triangularis, Stilostomella paleocenica, Tappanina selmensis, and Tritaxia midwayensis. Although this cluster is also dominated by epifaunal and infaunal deposit feeders, there is an occurrence of the infaunal suspension feeders Adhaerentia midwayensis and Tritaxia midwayensis and the outer neritic species Tap- panina selmensis in the upper part, and a distinct increase in diversity and abundance indicate an outer neritic paleoenvironment. This is another deepening upward HST.

\section{DISCUSSION AND CONCLUSION}

Using integrated stratigraphy, Paleocene sediments in the Island Beach borehole are divided into three sequences (pa1, pa2, and pa3). Each sequence is bounded by unconformities and associated hiatuses. Benthic foraminiferal biofacies analysis reveals that deposition of each sequence began in relatively deeper normal marine conditions and terminated in shallower neritic paleoenvironments, although one of the sequences (pa3) deepens upward.

Benthic foraminiferal biofacies have been widely used to interpret depositional paleoenvironments within sequences. Many studies have concluded that changes of benthic foraminiferal assemblages occur at the sequence boundaries because they usually coincide with missing sediments (e.g., Browning et al., Chapter 16, this volume). In the Paleocene section at Island Beach, the largest benthic foraminiferal biofacies changes, as shown by cluster analysis, occur at MFSs (marked by shell beds at 1158 and $1127.5 \mathrm{ft}$ [353.0 and $343.8 \mathrm{~m}$ ]; Fig. 3 ). This contrasts with studies of younger sediments that indicate that the largest biofacies changes occur at sequence boundaries (Browning et al., Chapter 16, this volume; Pekar and Miller, Chapter 15, this volume), although biofacies changes also occur at MFSs. To explain the changes observed in this study, one must understand the sedimentary regime in the New Jersey shelf during the Paleocene.

Water-depth changes are small across Paleocene sequence boundaries in New Jersey. This reflects a longer term decrease in water depth superimposed on these transgressive/regressive sequences. For 


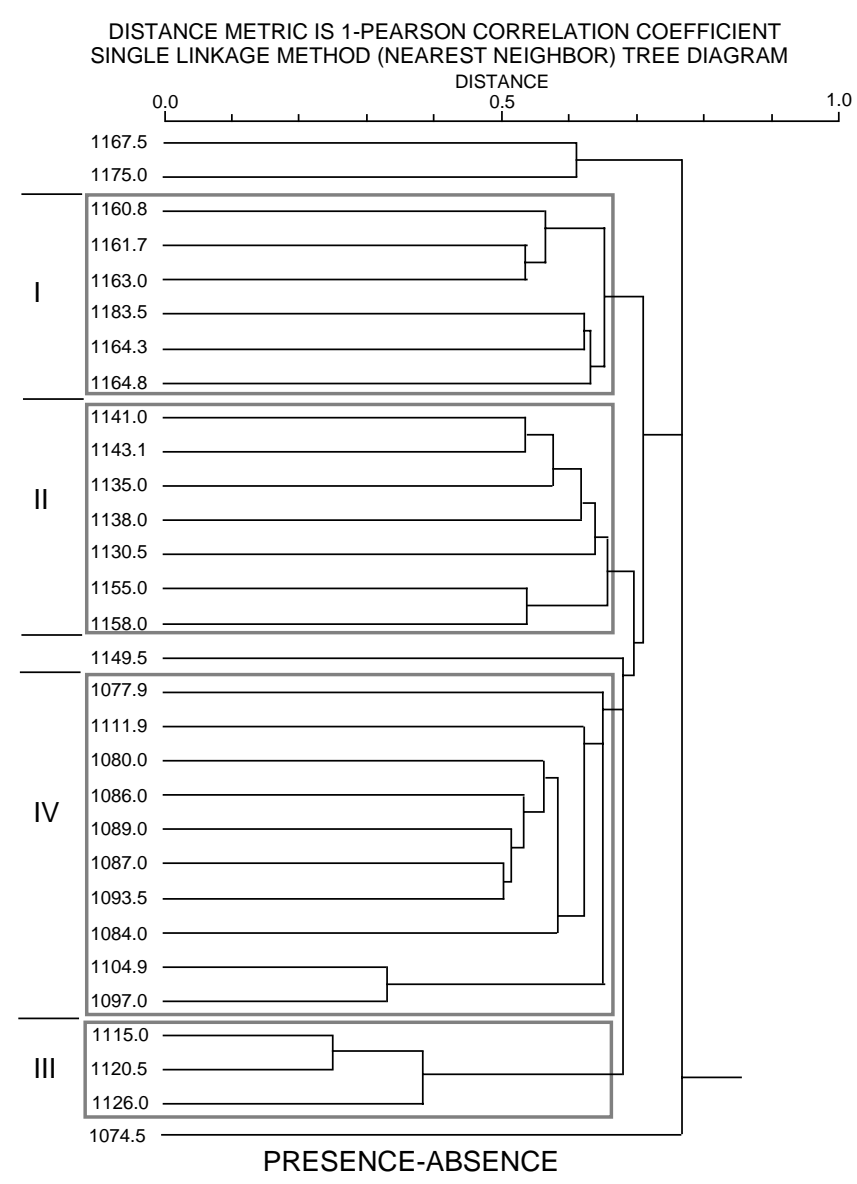

Figure 5. Q-mode (sample vs. sample) benthic foraminiferal biofacies cluster analysis of 30 samples from the Island Beach borehole. The distance metric is 1-Pearson correlation coefficient by single linkage method. A total of 119 species were identified, and 51 single occurring taxa were removed. Presence/absence data were used, because most samples do not contain enough specimens for reliable analysis of abundance data.

example, an upward decrease in water depth is clearly reflected within the HST of the pa1 sequence (Fig. 3). However, water depths at the base of the overlying pa2 sequence are only slightly deeper than at the top of pa1, owing to the longer term sea level fall.

We constructed an age-depth diagram that illustrates the duration of our hiatuses and shows differences between planktonic foraminiferal and calcareous nannoplankton biostratigraphy near the early/ late Paleocene boundary (Fig. 4). The occurrences of Praemurica uncinata, Igorina pusilla, Morozovella angulata, and Globanomalina pseudomenardii indicate a hiatus spanning Subzone P1c or perhaps lower Zone P2, but continuous deposition between Zones P3 and P5 (solid lines). However, the lowest occurrence of the nannofossil Fasciculithus tympaniformis (base Zone NP5) indicates that Zone NP4, equivalent to planktonic foraminiferal Zone P1c-P3b, is missing (dashed lines, Fig. 4). Possible explanations for this discrepancy include redeposition of Zones P2-P3 assemblages, earlier occurrence of $F$. tympaniformis, or displacement of Zone NP5 flora downward into older sediments via burrowing filling.

Four hiatuses are recognized within the Paleocene strata in the Island Beach borehole (Fig. 4).

1. The first hiatus spans the K/T boundary (to $63 \mathrm{Ma}$ ), based on the absence of Zones P0-P1b. However, the hiatus may be shorter than we estimated (Fig. 4), because the interval be- tween 1188 and $1184.25 \mathrm{ft}$ (362.2 and $361.1 \mathrm{~m}$ ) was not recovered, and updip sections show a shorter hiatus (Olsson and Wise, 1987a, 1987b).

2. The second hiatus straddles the early/late Paleocene boundary. Two age estimates are possible; the shorter ( 0.5 m.y.) is based on planktonic foraminiferal biostratigraphy (i.e., based on the absence of upper Subzone P1c-lower Zone P2), and the longer ( 2.5 m.y.) is based on nannofossil biostratigraphy (i.e., the absence of Zone NP4).

3. The third hiatus occurs in the late Paleocene ( 0.6 m.y.), based on the absence of Subzone P4b.

4. The last hiatus occurs in the latest Paleocene ( $<0.6$ m.y.). This hiatus probably spans the Paleocene/Eocene boundary (Miller, Chapter 1, this volume; Browning et al., Chapter 16, this volume; Bybell and Self-Trail, Chapter 9, this volume), although it is possible that it is restricted to the latest Paleocene (Pak et al., Chapter 23, this volume).

Based on planktonic foraminiferal biostratigraphy, all of the Paleocene hiatuses are short in duration (Fig. 4).

The earliest and latest Paleocene hiatuses are consistent with the TA1.1/1.2 and TA2.2/2.3/2/.4 inferred sea-level lowerings of Haq et al. (1987; Fig. 4). However, we do not detect the TA1.3 and TA2.1 inferred eustatic lowerings of Haq et al. (1987). The TA1.4 sequence is consistent with the nannofossil-based age estimate for the hiatus at the base of pa2, but not with the foraminiferal-based estimate (Fig. 4). Our $\sim 63.9-61.1 \mathrm{Ma}$ and 57.1-56.5 Ma hiatuses (= bases of the pa2 and pa3 sequences) appear to correlate with sea-level highs of Haq et al. (1987; Fig. 4). Our record also appears to differ in detail from those in Alabama, where Mancini and Tew (1991, 1993, 1995) report four early Paleocene and four late Paleocene sequences (Fig. 4). Although several of their sequence boundaries are consistent with ours (e.g., their TAGC-1.3 and TAGC-2.4), most of their sequences have no equivalent at Island Beach (Fig. 4).

Benthic foraminiferal biofacies presented here indicate a small amplitude of paleobathymetric change. This is consistent with the studies of Olsson and Wise (1987a, 1987b), but contrasts with estimates of Paleocene eustatic changes exceeding $150 \mathrm{~m}$ (Haq et al., 1987); the Island Beach Paleocene record does not indicate such large, rapid sea-level changes. Because the data that were used to generate the sea-level curve of Haq et al (1987) are not released, this dilemma will remain until more Paleocene data are available.

\section{ACKNOWLEDGMENTS}

We greatly appreciate review and comments by Drs. William A. Berggren and Berry H. Tew. Discussions with S. Pekar and P. Sugarman are greatly appreciated. Supported by NSF Grants EAR9218210 and EAR94-17108. This is LDEO contribution 5679.

\section{REFERENCES}

Buzas, M.A., and Gibson, T., 1973. Species diversity: Benthic foraminifera in western North Atlantic. Science, 163:72-75.

Haq, B.U., Hardenbol, J., and Vail, P.R., 1987. Chronology of fluctuating sea levels since the Triassic. Science, 235:1156-1167.

Koutsoukos, E.A.M., and Hart, M.B., 1990. Cretaceous foraminiferal morphogroup distribution patterns, paleocommunities and trophic structures: a case study from the Sergipe Basin, Brazil. Trans. Royal Soc. Edinburgh: Earth Sciences, 81:221-246.

Lipps, J.H., 1976. Feeding strategies and test function in foraminifera. Spec. Publ. Mar. Sedimentology, 1:100-110.

, 1982. Biology/paleobiology of foraminifera. In Broadhead, T. W. (Ed.), Foraminifera: Notes for a short course: Knoxville (Univ. Tennessee Press), 1-21.

, 1983. Biotic interactions in benthic foraminifera. In Tevesz, M.J.S., and McCall, P.L. (Eds.), Biotic interactions in Modern and Fossil Benthic Communities: New York (Plenum), 8:331-376. 
Mancini, E.A., and Tew, B.H., 1991. Relationship of Paleocene stage and planktonic foraminiferal zone boundaries to lithostratigraphic and allostratigraphic contacts in the eastern Gulf coastal Plain. J. Foraminiferal Res., 21:48-66.

, 1993, Ecstasy versus subsidence: lower Paleocene depositional sequences from southern Alabama. eastern Gulf Coastal Plain. Geol. Soc. Am. Bull., 105:13-17.

, 1995, Geochronology, biostratigraphy and sequence stratigraphy of a marginal marine to marine shelf stratigraphic succession: Upper Paleocene and lower Eocene, Wilcox group, eastern Gulf Coastal Plain, U.S.A. In Berggren, W.A., Kent, D.V., and Aubry, M.-P. (Eds.), Geochronology, time scales and global stratigraphic correlation. Spec. Publ.Soc. Econ. Paleontol. Mineral., 54:281-293.

Miller, K.G., Fairbanks, R.G., and Mountain, G.S., 1987. Tertiary oxygen isotope synthesis, sea-level history, and continental margin erosion. Paleoceanography, 2:1-19.

Miller, K.G., Sugarman, P., Van Fossen, M., Liu, C., Browning, J.V., Queen D., Aubry, M.P., Burckle, L.D., Goss, M., and Bukry, D., 1994. Island Beach site report. In Miller K.G., et al., Proc. ODP, Init. Repts., 150X: College Station, TX (Ocean Drilling Program), 5-33.

Olsson, R.K., 1991. Cretaceous to Eocene sea-level fluctuations on the New Jersey margin. Sediment. Geol., 70:195-208.

Olsson, R.K., and Wise, S.W., Jr., 1987a. Upper Maestrichtian to middle Eocene stratigraphy of the New Jersey slope and coastal plain. In van
Hinte, J.E., Wise, S.W., Jr., et al., Init. Rep. DSDP, 93 (Pt. 2): Washington (U.S. Govt. Printing Office), 1343-1365.

1987b. Upper Paleocene to middle Eocene depositional sequences and hiatuses in the New Jersey Atlantic Margin. In Ross, C., and Haman, D. (Eds.), Timing and Depositional History of Eustatic Sequences: Constraints on Seismic Stratigraphy. Spec. Publ. Cushman Found. Foraminiferal Res., 24: 99-112.

Owens, J.P., and Minard, J.P., 1964. Pre-Quaternary geology of Pemberton quadrangle, New Jersey. USGS Geol. Quad. Map, GQ-262.

Pitman, W.C., III, and Golovchenko, X., 1983. The effect of sea level change on the shelf edge and slope of passive margins. Spec. Publ.-Soc. Econ. Paleontol. Mineral., 33:41-58.

Poag, C.W., and Sevon, W.D., 1989. A record of Appalachian denudation in postrift Mesozoic and Cenozoic sedimentary deposits of the U.S. middle Atlantic continental margin. Geomorphology, 2:119-157.

Steckler, M.S., and Watts, A.B., 1978. Subsidence of the Atlantic-type continental margin off New York. Earth Planet. Sci. Lett., 41:1-13.

Date of initial receipt: 11 March 1996

Date of acceptance: 4 September 1996 Ms 150XSR-316 